\section{AUTHOR}

SIMONE POLEDRINI

Department of Economics, University of Perugia (Italy)

simone.poledrini@unipg.it

\section{FLORENCE DEGAVRE}

Institute for the Analysis of Change in Contemporary and Historical Societies (IACCHOS), Centre Interdisciplinaire

de Recherche Travail Etat et Société (CIRTES),

Université Catholique de Louvain (Belgium)

florence.degavre@uclouvain.be

\section{ERMANNO TORTIA}

Department of Economics and Management, University of Trento; European Research Institute on Cooperative and Social

Enterprises (Euricse) (Trento, Italy)

ermanno.tortia@unitn.it

\title{
Editorial: Background and Further Perspectives on Social Innovation in Social Enterprises
}

\section{ABSTRACT}

The last few years have marked many theoretical and practical contributions to the field of social innovation and social enterprise. However, most of these contributions lack analysis linking these subjects. This editorial article, written for the JEOD special issue Social innovation in social enterprises: what is going on?, aims to fill the gap. The issue presents some case studies on social innovation in social enterprises, as well as theoretical implications and key aspects. The editorial concludes by presenting a summary of each article.

\section{KEY-WORDS}

\section{Acknowledgments}

The authors wish to thank Carlo Borzaga and Silvia Sacchetti for guest editing this special issue, all authors for their insightful contributions, and the anonymous reviewers for their help and comments. Our special thanks also go to Barbara Franchini and Stefania Chiomento for their editorial assistance. 


\section{Introduction}

Although the topic of social innovation is not new, it has attracted considerable attention in recent years from scholars in a wide range of disciplines. While most initial contributions came from economics (Pol and Ville, 2009) or sociology (Olsson and Galaz, 2012), new insights have emerged from management studies (Cajaiba-Santana, 2014), psychology (Bulut, Eren and Halac, 2013), gender studies (André, 2013; Alsos, Hytti and Ljunggren, 2016), or else from an interdisciplinary or transdisciplinary framework (Dedeurwaerdere et al., 2017; Haxeltine et al., 2017). One common element is questioning the transformative potential of social innovation. Still, social innovation theory remains somewhat fragmented as these different approaches lead to an equally varied number of definitions and analytic frameworks (Gallouj and Djellal, 2010; Nicholls and Murdock, 2012; Moulaert et al., 2013; Ayob, Teasdale and Fagan, 2016).

Social enterprises are organizations that combine entrepreneurial dynamics to provide services or goods with the primary objective of meeting social needs (Borzaga and Defourny, 2001). Social enterprises (SEs) drive social innovation (Harrisson, Klein and Browne, 2010; Defourny and Nyssens, 2013). While social innovation within social enterprises has been studied extensively, its long-term effect upon those social enterprises themselves is less well-understood. This special issue addresses the following research questions: What drives social enterprises to innovate? What are the main implications of the connection between social innovation and social enterprise?

To answer these questions, this editorial draws upon existing literature. The first section shows that social innovation is closely linked to voluntary social transformation driven by people or organizations. The following section presents the central feature that SEs usually have that pushes them to socially innovate. Section 3 discusses some critical aspects of social innovation in social enterprises, while the last section summarizes the articles published in this special issue.

\section{Looking for alternatives: the need for social innovation}

Our perspective considers social innovation as an effort to "unlock" economic or social systems deeply rooted in path dependency. The explicit use of the term social innovation dates back to the late 1960s. It is rooted in the "counter-culture" (Roszak, 1969) that spread across the Western world, Latin America, and Japan. Both disaffected youth and workers longing for a more democratic organization of labour contested the status quo. So-called "alternative companies" emerged in the 1970s, driven by aspirations to work and produce differently. These companies adopted self-management or non-capitalist division of labour or offered services that were neglected by the market or by the state. Social actors used the term "social innovation" to refer to the dailylife practice of their global vision regarding how goods should ideally be produced and consumed. The term was strongly connected to alternative production processes (Callorda Fossati, Degavre and Lévesque, 2018). 
The necessity of social innovations beyond these alternative companies soon became clear. Forprofit companies also struggling with capitalist competition and facing workplace issues difficult to solve purely through technological innovation also stood to benefit. Worried about Japanese technological advancement, especially in the car industry, employers in the 1980s in Europe and the United States imposed major technological changes upon their workers. Meanwhile, workers rallied to take part in the decision-making process and to master new technology. Employers needed productive flexibility while workers were asking for democratic flexibility. In the end, trade unions supported a compromise granting "controlled autonomy" in the work place (Appay, 1997); this measure was considered the best way to maintain competitiveness and preserve jobs, and had little to do with fulfilling workers' aspirations. Social innovation then remained limited to what Laville (2014) and Nyssens (2015) call a "weak conception", in which solutions were proposed at the level of the enterprise, avoiding the prospect of sustainable institutional change through public policy as well as of substantive workplace policy improvement (Callorda Fossati, Degavre and Lévesque, 2018). This historical episode perfectly illustrates why Ayob, Teasdale and Fagan (2016) are speaking of an "essentially contested concept", as social innovation is subject to power relations and to "endless disputes" about its meaning (Callorda Fossati, Degavre and Nyssens, 2017).

In the 1990s, the notion of social enterprise expanded to include public services. Public service users started to question their treatment and criticized deeply inadequate standard service provision. Social enterprises like social cooperatives and non-profit organizations, known as the social economy, took over unmet social needs, solving problems in diverse fields including personal services, work integration, environmental protection, fair trade, and community development. These social actors mainly reacted against the limitations imposed by public action and the market. Social enterprises also helped sustain stakeholder' more immaterial aspirations such as participatory governance, service co-creation, and changing social relations.

From this perspective, innovations are inherently social because they are carried out to positively transform social relations for non-dominant groups. The most well-conceived innovations are powerful enough to challenge established power relations and diffuse throughout society, bringing change (Moulaert et al., 2010). In that respect, the 2008 financial crisis confirmed that social enterprises must be at the forefront of creative solutions to the multi-dimensional problems created by neo-liberalism. Social enterprises still face new challenges, especially related to ecological and social transition: climate change, ageing of the population, intersectional inequalities, migration, lodging, and mobility. Social enterprises have significant potential to meet the transition challenge and foster social innovations in their related domains, alongside technological innovations. Some social enterprises are already acting as "transition experiments" on a small scale. These "project[s] with a societal challenge as a starting point for learning aimed at contributing to a transition" (Van den Bosch, 2010: 58) will help change production processes and consumption patterns. 
More insight regarding social innovation's effects on social enterprises is necessary for three interconnected reasons:

1. In order to reach a significant level of social impact, a better understanding of the mechanisms of innovation within social enterprises must be reached; how can new collaborations within a transdisciplinary framework or through participative local governance influence global transitions?

2. Non-profit organizations frequently lament that their decades of consistent social innovation have never been acknowledged. What has changed is that academia, public policy actors, and other stakeholders have started to use the term. As a concept, social innovation is used to highlight, often retrospectively, big social disruptions as well as small improvements to communities' conditions with a focus on the vision at stake.

3. Social innovation is strongly associated with the process of challenging existing institutions, power relations, and governance. There is a need now to critically assess social innovation's processes from within and address the issue of the dark side of social innovations. Potential backlash to and consequences of social innovation have yet to be explored. Participating in innovation can generate stress, frustration, and demotivation, decreasing the pro-social initiative characteristic of those who work in social enterprise. How can social enterprises contribute to transition while keeping innovations social in all their aspects? Meaningful and carefully chosen case studies such as those in this issue can best improve understanding of what innovation means for social enterprises and stakeholders acting in a field.

\section{The premises of social innovation in social enterprises}

Theoretical arguments, case studies, and surveys can now be combined to examine how social enterprises truly do enhance social innovation. An exhaustive framework is beyond this brief editorial's scope. We will only outline the elements proven conducive to social innovation, which include: (i) the intrinsic and pro-social motivations of the actors involved; (ii) collective action and cooperation, in place of market exchanges and hierarchical relations, as the dominant coordination mechanisms; (iii) multi-stakeholder governance and corporate social responsibility as criteria of social inclusion and fairness; (iv) the non-profit oriented nature of the organization. We start from individual and collective behavioural dimensions (motivations and collective action), and then proceed to more hard-wired institutional dimensions (multi-stakeholder governance and limited profit distribution). We explain these elements one at a time and develop preliminary arguments concerning social innovation in social enterprises.

(i) Intrinsic and pro-social motivations of the involved actors. The importance of intrinsic and pro-social motivations has been rediscovered in economics in the last decades, beginning with a few pioneering works that borrowed the concept and then the experimental apparatus from social 
psychology (Deci and Ryan, 1975; 2000a; 2000b; Frey, 1997). This concept's importance has since increased, especially relating to the growth of behavioural and experimental economics (Fehr and Schmidt, 1999; Fehr and Gächter, 2000). These concepts are prominent in non-profit and third sector research as well (Young, 1983; 1984; 2001; Rose-Ackerman, 1996). Altruism, trust, reciprocity, and cooperation have been "bread and butter" for many scholars searching for the nonprofit difference and striving to explain the existence, growth, and sustainability of socially oriented organizations. While non-profit and third sector research used to be separate from mainstream economics, interconnections are growing, particularly in research streams dealing with corporate social responsibility (Sacconi, 2004; Freeman, 2010; Sacconi and Ottone, 2015) and shared capitalism (Kruse, Freeman and Blasi, 2008; Kruse, Blasi and Park, 2010). The importance of prosocial motivations, besides intrinsic motivations, has extended to the managerial disciplines in more recent years (Grant and Berry, 2011; Grant and Berg, 2012)

(ii) Collective action and cooperation. These aspects are usually understood as an economic activity coordination mechanism alternative to traditional coordination mechanisms (market exchange and hierarchy). Contrasting with conventional, profit-oriented enterprises, these coordination mechanisms have demonstrated their fundamental role in cooperative and social enterprises, and more generally in non-profit oriented enterprises. In the absence of profit motivation and highpowered monetary incentives that drive the firm's organization (Alchian and Demsetz, 1972; Jensen and Meckling, 1976), coordination must be achieved via different avenues. Hierarchy, as identified in the literature initiated by Ronald Coase (1937) and continued by Oliver Williamson (1973; 1975; cf. also Simon, 1951), functions in conventional enterprises to maximize profit. In non-profit enterprises hierarchy may not improve, but instead damage social objectives because of its negative impact on intrinsic and pro-social motivations, as well as its inability to favour participation in the pursuit of collective goals (Valentinov, 2009; Grant and Patil, 2012). The potential limitations of collective action, especially the problem of free riding and other forms of opportunism in the pursuit of collective goals (Olson, 1965; Hardin, 1968; Ostrom, 1990), have generated renewed debate regarding how the governance of collective action can counteract opportunism and favour virtuous and welfare-increasing organizational solutions despite tragedy of the commons-like conditions (Ostrom, 1990; Ostrom and Basurto, 2007; Hansmann, 2013; Benkler, 2017; Tortia, 2018). Cooperation is seen as a necessary feature of collective action. Cooperation itself, and the underlying reciprocal behaviours, can counteract opportunism by means of involvement, but also through peer pressure and horizontal control, as well as sanctions punishing non-complying individuals and offenders (Borzaga and Tortia, 2017; Tortia and Valentinov, 2018).

(iii) Multi-stakeholder governance. The relevance of multi-stakeholder governance has, again, been ascertained in theoretical and empirical studies on non-profit and socially-oriented enterprises. Such governance led to re-evaluation of strategic management's role and its benefits for different groups of stakeholders (Blair and Stout, 1999; Sacconi, 2004; Freeman, 2010; Sacconi and Ottone, 2015). The impossibility of excluding stakeholder groups apart from investors from the definition of the organization's strategic objectives led to their inclusion in managerial decisions, and to the 
development of new analytic frameworks and theories required to explain the new concept of the enterprise. It also led to questioning the existing institutional set-ups and to proposals for reformation and for the introduction of new organizational forms. Social enterprises were born in this milieu of creativity and new solutions, which could have led to the realization of social goals once thought to be unattainable by organizations outside the public sector. The new frameworks have strived to explain why non-profit organizations, contrary to the prediction of orthodox and newinstitutional economics (Hansmann, 1996), can achieve efficient production and be more effective than conventional enterprises in delivering general interest services and collective goods (Borzaga and Sacchetti, 2015; Sacchetti and Tortia, 2017). Procedural, interactional, and distributive fairness plays a particularly strong role in guaranteeing a high degree of welfare for involved actors. A fair organizational context would at least partly make up for some financial weaknesses, including weak monetary incentives and low labour remuneration (Tortia, 2008; Borzaga and Tortia, 2017).

(iv) Limited (or absent) profit distribution. The existence and economic motivation of the nonprofit-distribution constraint came under scrutiny right from the start of research on non-profit organizations. Burton Weisbrod (1977; 1988) and Henry Hansmann (1988; 1996) pioneered studies on non-profit organizations in which the non-distribution constraint acts as a crucial institutional device guaranteeing the possibility for non-profits to produce public goods and to reduce the opportunistic behaviour of the organization in the presence of asymmetric information and of a high relational content of the service provided (Borzaga and Tortia, 2017; Tortia and Valentinov, 2018; Poledrini and Tortia, 2018). The absence of the profit motivation and the lower relevance of monetary incentives (especially high-powered monetary incentives, such as profit sharing) would explain the emergence of trust and cooperation between the main stakeholders, both external (between the organization and its clients or users) and internal (between managers and workers) (Bacchiega and Borzaga, 2001; 2003). Cooperation is closely related to the underlying mechanism of reciprocal behaviours, which can be both conditional and unconditional (Poledrini, 2015).

\section{Social innovation in social enterprises}

The theory of social innovation in SEs is controversial. Historical reconstruction might provide the rough material necessary to work out a better integrated theory of social innovation in social enterprises. This difficult endeavour cannot and will not be completed here. However, some preliminary hints may presage future understanding. While social innovation can and indeed does take place outside organizational boundaries, non-profit and social enterprises only represent the specific organizational form that develops the routines, governance solutions, and managerial models most conducive to social innovation as the outcome of organized social relations. While the four elements are always present in social enterprises, this does not mean that they are absent from other contexts. They can be found at least partially in other individuals, social contexts, and 
organizations. Social enterprises strive to combine the elements in an innovative way. SEs came to represent privileged social contexts in which these elements can be combined to produce relevant outcomes, such as social innovation.

The four elements can be used to explain why social innovation can be the highest and most creative achievement of social enterprises. Collective action based on trust and cooperation is clearly functional to the achievement of collective rather than private goals. These organizational elements can better flourish and deploy their beneficial effects in organizations that do not pursue profit maximization and private goals, and which are partially or totally constrained in profit distribution. Non-profit nature and collective action are compatible with goals that are social in nature and may not be forthcoming or be marginalized in organizations pursuing private objectives. Multi-stakeholder governance and corporate social responsibility can be seen as social patterns informed by inclusion in place of exclusion (Sacchetti, 2015). Motivations play a crucial role in all of this. Intrinsic and pro-social motivations are not thought of as a behavioural element created by social enterprises. Instead, their importance is clearly connected with the heterogeneity of individual preferences and with the self-selection of socially motivated individuals into social enterprises (Simpson and Willer, 2008). Social enterprises are thought to reinforce and exalt the role of pro-social motivations, not to create them anew. Social innovation can emerge as the creative expression of intrinsic and prosocial motivations in a suitably constructed institutional environment. This statement emerges as intuitively coherent with its theoretical premises. However, it is not devoid of empirical content. It has led, and is leading to the development of important streams of empirical research, which are most often qualitative and based on case studies, as they require in-depth evaluation of the organizational mechanisms most conducive to innovative social outcomes (processes, services, and goods). Social enterprises, indeed, are proving to be innovative not only in terms of processes and services delivered, but also in terms of their ability to envision and plan interventions in different social contexts (e.g. urban vs. rural). These interventions regenerate natural spaces and communities through environmental intervention and protection, and the reorganization of urban spaces (Sacchetti, Christoforou and Mosca, 2018).

\section{How social innovation affects social enterprise}

Building on the above remarks, the four articles published in this special issue broaden our understanding of social innovation in social enterprises through empirical research.

The first article, by Nick Bailey, Reinout Kleinhans, and Jessica Lindbergh is titled The implications of Schumpeter's theories of innovation for the role, organization, and impact of communitybased social enterprise in three European countries. It uses Schumpeter's work as a lens to view the effects of social innovation on different aspects of social enterprises. In particular, it answers the following research questions: (i) To what extent can community-based social enterprise (CBSE) be considered a form of social innovation and how does this innovation arise in terms of the role, 
organization, and impact of CBSEs? (ii) What are the similarities and differences between CBSEs in the three selected European countries? (iii) To what extent does Schumpeter's conceptual framework of "creative destruction" provide insights into the process of organizational change in this form of social enterprise? To answer these questions, the authors develop an empirical analysis based on nine in-depth case studies of community-based social enterprises in England, the Netherlands, and Sweden. The results show that, as the so-called community-based characteristics of the organizations (in terms of participation, governance, and funding) differ largely from one country to another, the establishment and evolution of CBSEs in the three analysed countries follow quite different paths, especially regarding the commercial and social mission.

The second paper, by Philip Marcel Karré, is titled Navigating between opportunities and risks: the effects of hybridity for social enterprises engaged in social innovation and it identifies what drives social entrepreneurs to engage in social innovation processes, how they generate results, and how they deal with tensions due to hybridity. The author addresses the following four research questions: (i) Why do social entrepreneurs decide to engage in processes of social innovation? (ii) How are they trying to achieve social innovation? (iii) To what extent is hybridity an issue in this process? (iv) What is the relationship between the social entrepreneur and the local government in this process? He looks at an urban subset of social enterprises engaged in social innovation, as his answers are based on a study of social enterprises in and around the cities of Rotterdam, The Hague, and Dordrecht in the Netherlands. His main findings demonstrate several reasons for social entrepreneurs to engage in social innovation processes. These reasons are all closely connected to personal experiences and life events.

The third article, by Ralph Richter, is titled The Janus face of participatory governance: how inclusive governance benefits and limits the social innovativeness of social enterprises. The article deals with how social innovation is developed in a social enterprise considering that SEs usually have participatory governance. The article answers the following research question: does collaborative decision-making hamper the development of innovative solutions or do social enterprises benefit from their capacity to innovate? Indeed, since according to Schumpeter developing innovative products, services, and processes is a distinguished capacity of the entrepreneur's personality, the author wonders whether participatory governance can have consequences on a social enterprise's capacity to develop new ideas and establish innovative solutions. This question guided cross-case analysis of four social enterprises. The results show that participatory governance can have different consequences on the innovative strength of social enterprises. While the involvement of internal stakeholders (members and employees) appears to be beneficial for developing novel solutions, it generates limited social impact. Close collaboration with external stakeholders, such as local communities or regional authorities, is less advantageous with respect to identifying new trends, ideas, and opportunities. However, the involvement of external stakeholders in decision-making helps safeguard of community interests and the legitimization of social enterprise activities. Therefore, the results suggest that a balanced involvement of both internal and external stakeholders 
enhances the social innovativeness of social enterprises.

The fourth article, by Marina Soubirou, is titled The No TAV entrepreneurs' transition towards a sustainable solidarity economy: pragmatic analysis of a social innovation process and it analyses whether a sustainable solidarity economy can overcome conflicts. The research concerns the No TAV movement in the lower part of the Susa Valley in Italy. This movement originated in the 1990s when this area witnessed the presence of a territorial conflict pitting the local inhabitants against the Italian state over the construction of a $54 \mathrm{~km}$ long railway tunnel under the Alps connecting Italy and France (more specifically, the cities of Turin and Lyon). By harshly rejecting this project and through collective participation in numerous resistance movements, the Low-Valsusans have gradually become a territorialized community whose members seem to share a set of sustainable principles and values. Using the theoretical framework of social innovations, the author shows how entrepreneurs are gradually getting involved in implementing their community's sustainable values to tackle conflicts.

Finally, Andrew Brady concludes the special issue with a book review on Innovation and Scaling for Impact: How Effective Social Enterprises Do It by Christian Seelos and Johanna Mair (Stanford University Press, Stanford, CA, United States, 2017, 256 pp.). The book is particularly relevant for offering an insightful and theory-rich contribution to the academic literature on the topic of social innovation in SEs. Based on empirical research, it presents the history of innovation and scaling up in four organisations located in India and Bangladesh, each of which is used to shed light on a particular approach to the process. Among other academic recognitions, it is worth to mention that the book received the 2017 Terry McAdam Nonprofit Book Award, sponsored by the Alliance for Nonprofit Management, for being the most inspirational and useful contribution to non-profit management of the year.

\section{References}

Alchian, A.A. \& Demsetz, H. (1972). Production, Information Costs, and Economic Organization, The American Economic Review, 62(5): 777-795.

Alsos, G.A., Hytti, U. \& Ljunggren, E. (2016). Research Handbook on Gender and Innovation. Cheltenham, UK: Edward Elgar Publishing. DOI: https://doi.org/10.4337/9781783478132

Andre, I. (2013). Gender and Social Innovation: The Role of EU Policies. In: F. Moulaert, D. MacCallum, A. Mehmood, A. Hamdouch (Eds.), The International Handbook on Social Innovation. Collective Action, Social Learning and Transdisciplinary Research. Cheltenham, UK: Edward Elgar Publishing. DOI: https://doi.org/10.4337/978184 9809993.00049

Appay, B. (1997). Précarisation sociale et restructurations productives. In: B. Appay \& A. Thébaud-Mony (Eds.), Précarisation sociale, travail et santé. IRESCO, pp. 509-554.

Ayob, N., Teasdale, S. \& Fagan, K. (2016). How Social Innovation "Came to Be": Tracing the Evolution of a Contested Concept, Journal of Social Policy, 45(4): 635-653. DOI: https://doi.org/10.1017/S004727941600009X

Bacchiega, A. \& Borzaga, C. (2001). Social enterprise as incentive structures. An economic analysis. In: C. Borzaga \& J. Defourny (Eds.), The Emergence of Social Enterprise. London: Routledge, pp. 273-95. 
Bacchiega, A. \& Borzaga, C. (2003). The Economics of the Third Sector. Toward a More Comprehensive Approach. In: H.K. Anheier \& A. Ben-Ner (Eds.), The Study of the Nonprofit Enterprise. Theories and Approaches. New York, NY: Kluwer Academic/Plenum Publishers, pp. 27-48.

Benkler, Y. (2017). Peer Production, the Commons, and the Future of the Firm, Strategic Organisation, 15(2): 264-274. DOI: https://doi.org/10.1177/1476127016652606

Blair, M.M. \& Stout, L.A. (1999). A Team Production Theory of Corporate Law, Virginia Law Review, 85(2): 247-328. DOI: https://doi.org/10.2307/1073662

Borzaga, C. \& Defourny, J. (Eds.) (2001). The emergence of social enterprise. London: Routledge.

Borzaga, C. \& Sacchetti, S. (2015). Why Social Enterprises Are Asking to Be Multi-stakeholder and Deliberative: An Explanation around the Costs of Exclusion, Euricse Working Papers, 75|15.

Borzaga, C. \& Tortia, E.C. (2017). Co-operation as Coordination Mechanism: A New Approach to the Economics of Co-operative Enterprises. In: J. Michie, J. Blasi \& C. Borzaga (Eds.), The Oxford Handbook of Mutual, CoOperative, and Co-Owned Business. Oxford: Oxford University Press, pp 55-75.

Bulut, C., Eren, H. \& Halac, D.S. (2013). Social Innovation and Psychometric Analysis, Procedia - Social and Behavioral Sciences, 82: 122-130. DOI: https://doi.org/10.1016/j.sbspro.2013.06.235

Cajaiba-Santana, G. (2014). Social innovation: Moving the field forward. A conceptual framework, Technological Forecasting and Social Change, 82: 42-51. DOI: https://doi.org/10.1016/j.techfore.2013.05.008

Callorda Fossati, E., Degavre, F. \& Lévesque, B. (2018). Linnovation sociale: retour sur les marches d'une construction théorique et pratique. Entretien avec Benoît Lévesque, Revue de la régulation [On line], 23(1). Available at: http://journals.openedition.org/regulation/12980 [Accessed: 18 August 2018].

Callorda Fossati, E., Degavre, F. \& Nyssens, M. (2017). How to deal with an "essentially contested concept" on the field? Sampling social innovations through the Delphi method, European Public \& Social innovation Review, 2(1): 4558.

Coase, R.H.(1937). The Nature of the Firm, Economica,4(16):386-405.DOI: https://doi.org/10.1111/j.1468-0335.1937. tb00002.x

Deci, E.L. \& Ryan, R.M. (1975). Intrinsic Motivation. New York, NY: Plenum Press. DOI: https://doi.org/10.1007/978$1-4613-4446-9$

Deci, E.L. \& Ryan, R.M. (2000a). The "What" and "Why" of Goal Pursuits: Human Needs and the Self-Determination of Behavior, Psychological Inquiry, 11(4): 227-268. DOI: https://doi.org/10.1207/S15327965PLI1104_01

Deci, E.L. \& Ryan, R.M. (2000b). Self-Determination Theory and the Facilitation of Intrinsic Motivation, Social Development, and Well-being, American Psychologist, 55(1): 68-78. DOI: https://doi.org/10.1037/0003066X.55.1.68

Dedeurwaerdere, T., De Schutter, O., Hudon, M., Mathijs, E., Annaert, B., Avermaete, T., Bleeckx, T., de Callatä̈, C., DeSnijder, P., Fernández-Wulff, P., Joachain, P., Vivero, J.-L. (2017). The Governance Features of Social Enterprise and Social Network Activities of Collective Food Buying Groups, Ecological Economics, 140: 123-135. DOI: https://doi.org/10.1016/j.ecolecon.2017.04.018

Defourny, J. \& Nyssens, M. (2013). Social innovation, social economy and social enterprise: what can the European debate tell us? In: F. Moulaert, D. MacCallum, A. Mehmood \& A. Hamdouch (Eds.), The International Handbook on Social Innovation. Collective Action, Social Learning and Transdisciplinary Research. Cheltenham, UK: Edward Elgar Publishing, pp. 40-52. DOI: https://doi.org/10.4337/9781849809993.00013

Fehr, E. \& Gächter, S. (2000). Fairness and Retaliation: The Economics of Reciprocity, Journal of Economic Perspectives, 14(3): 159-181. DOI: https://doi.org/10.1257/jep.14.3.159

Fehr, E. \& Schmidt, K.M. (1999). A Theory of Fairness, Competition, and Cooperation, The Quarterly Journal of Economics, 114(3): 817-868. DOI: https://doi.org/10.1162/003355399556151

Freeman, R.E. (2010). Strategic Management: A Stakeholder Approach. Cambridge: Cambridge University Press. DOI: https://doi.org/10.1017/CBO9781139192675 
Frey, B.S. (1997). Not Just for the Money An Economic Theory of Personal Motivation. Cheltenham, UK: Edward Elgar Publishing.

Gallouj, F. \& Djellal, F. (Eds.) (2010). The Handbook of Innovation and Services. A Multi-disciplinary Perspective. Cheltenham, UK: Edward Elgar Publishing. DOI: https://doi.org/10.4337/9781849803304

Grant, A.M. \& Berg, J.M. (2012). Prosocial motivation at work: How making a difference makes a difference. In: K. Cameron \& G. Spreitzer (Eds.), Oxford Handbook of Positive Organizational Scholarship. New York, NY: Oxford University Press, pp. 28-44.

Grant, A.M. \& Berry, J.W. (2011). The necessity of others is the mother of invention: Intrinsic and prosocial motivations, perspective taking, and creativity, Academy of Management Journal, 54(1): 73-96. DOI: https://doi.org/10.5465/ amj.2011.59215085

Grant, A.M. \& Patil, S.V. (2012). Challenging the norm of self-interest: Minority influence and transitions to helping norms in work units, Academy of Management Review, 37(4): 547-568. DOI: https://doi.org/10.5465/ amr.2010.0437

Hansmann, H. (1988). Ownership of the Firm, Journal of Law, Economics, and Organization, 4(2): 267-304.

Hansmann, H. (1996). The Ownership of Enterprise. Cambridge, MA: Harvard University Press.

Hansmann, H. (2013). All firms are cooperatives - and so are governments, Journal of Entrepreneurial and Organizational Diversity, 2(2): 1-10. DOI: http://dx.doi.org/10.5947/jeod.2013.007

Hardin, G.J. (1968). The tragedy of the commons, Science, 162: 1243-1248.

Harrisson, D., Klein, J.-L. \& Browne, P.L. (2010). Social innovation, social enterprise and services. In: F. Gallouj \& F. Djellal (Eds.), The Handbook of Innovation and Service. A Multi- disciplinary Perspective. Cheltenham, UK: Edward Elgar Publishing, pp. 197-218.

Haxeltine, A., Pel, B., Dumitru, A., Avelino, F., Kemp, R., Bauler, T., Kunze, I., Dorland, J., Wittmayer, J. \& Jørgensen, M.S. (2017). Towards a TSI theory: a relational framework and 12 propositions, TRANSIT Working Paper 16.

Jensen, M.C. \& Meckling, W.H. (1976). Theory of the firm: Managerial behavior, agency costs and ownership structure, Journal of Financial Economics, 3(4), 305-360. DOI: https://doi.org/10.1016/0304-405X(76)90026-X

Kruse, D., Blasi, J. \& Park, R. (2010). Shared Capitalism in the U.S. Economy: Prevalence, Characteristics, and Employee Views of Financial Participation in Enterprises. In: D. Kruse, R. Freeman \& J. Blasi (Eds.), Shared Capitalism at Work: Employee Ownership, Profit and Gain Sharing, and Broad-based Stock Options. Chicago, IL: University of Chicago Press, pp. 41-75. DOI: https://doi.org/10.7208/chicago/9780226056968.003.0002

Kruse, D., Freeman, R. \& Blasi, J. (2008). Do Workers Gain by Sharing? Employee Outcomes under Employee Ownership, Profit Sharing, and Broad-based Stock Options, National Bureau of Economic Research Working Paper No. 14233. Available at: http://www.nber.org/papers/w14233 [Accessed 20 August 2018]

Laville, J.-L. (2014). Innovation sociale, économie sociale et solidaire, entrepreneuriat social. Une mise en perspective historique. In: J.L. Klein, J.L. Laville \& F. Moulaert, L'innovation sociale. Toulouse, ERES, Collection Sociologie économique, p. 45-80.

Moulaert, F., MacCallum, D., Mehmood, A. \& Hamdouch, A. (Eds.) (2013). The International Handbook on Social Innovation. Collective Action, Social Learning and Transdisciplinary Research. Cheltenham, UK: Edward Elgar Publishing. DOI: https://doi.org/10.4337/9781849809993

Moulaert, F., Swyngedouw, E., Martinelli, F., Gonzalez, S. (2010). Can Neighbourhoods Save the City? Community Development and Social Innovation. London and New York: Routledge. DOI: https://doi.org/10.4324/9780203849132

Nicholls, A. \& Murdock, A. (Eds.) (2012). Social Innovation: Blurring Boundaries to Reconfigure Markets. London: Palgrave Macmillan UK. DOI: https://doi.org/10.1057/9780230367098

Nyssens, M. (2015). L'innovation sociale et l'entreprise sociale: quels dialogues possibles? Une perspective européenne. In: J.-L. Klein, A. Camus, C. Jetté, C. Champagne \& M. Roy, La transformation sociale par l'innovation sociale. Québec: Presses de l'Université du Québec, p. 335-348. 
Olson, M. (1965). The Logic of Collective Action. Public Goods and the Theory of Groups. Cambridge, MA: Harvard University Press.

Olsson, P. \& Galaz, V. (2012). Social-Ecological Innovation and Transformation. In: A. Nicholls \& A. Murdock (Eds.), Social Innovation: Blurring Boundaries to Reconfigure Markets. London: Palgrave Macmillan UK, pp. 223-247. DOI: https://doi.org/10.1057/9780230367098_10

Ostrom, E. (1990). Governing the Commons. The Evolution of Institutions for Collective Action. Cambridge, UK: Cambridge University Press. DOI: https://doi.org/10.1017/CBO9780511807763

Ostrom, E. \& Basurto, X. (2011). Crafting analytical tools to study institutional change, Journal of Institutional Economics, 7(3): 317-343. DOI: https://doi.org/10.1017/S1744137410000305

Pol, E. \& Ville, S. (2009). Social innovation: Buzz word or enduring term?, The Journal of Socio- Economics, 38(6): 878-885. DOI: https://doi.org/10.1016/j.socec.2009.02.011

Poledrini, S. (2015). Unconditional Reciprocity and the Case of Italian Social Cooperatives, Nonprofit and Voluntary Sector Quarterly, 44 (3), 457-473. DOI: https://doi.org/10.1177/0899764013518844

Poledrini, S. \& Tortia, E. (2018). L'impresa sociale italiana nella prospettiva economico-manageriale, Analisi Giuridica dell'Economia, 1, in press.

Rose-Ackerman, S. (1996). Altruism, Nonprofits, and Economic Theory, Journal of Economic Literature, 34(2): 701-728.

Roszak, T. (1969). The Making of a Counter Culture: Reflections on the Technocratic Society and Its Youthful Opposition. New York, NY: Anchor Books.

Sacchetti, S. (2015). Inclusive and exclusive social preferences: a Deweyan framework to explain governance heterogeneity, Journal of Business Ethics, 126(3): 473-485. DOI: https://doi.org/10.1007/s10551-013-1971-0

Sacchetti, S., Christoforou, A. \& Mosca, M. (2018). Social Regeneration and Local Development. Cooperation, Social Economy and Public Participation. New York, NY: Routledge.

Sacchetti, S. \& Tortia, E.C. (2017). The notion of social responsibility across different types of nonprofit and for profit organizations, Econometica Working Paper 61. Available at: http://econometica.it/wp/wp61.pdf [Accessed 21 August 2018]

Sacconi, L. (2004). Corporate Social Responsibility (CSR) as a Model of "Extended" Corporate Governance. An Explanation Based on the Economic Theories of Social Contract, Reputation, and Reciprocal Conformism, Liuc Papers, 142. Available at: http://www.biblio.liuc.it/liucpap/pdf/142.pdf [Accessed 9 February 2017].

Sacconi, L. \& Ottone, S. (Eds.) (2015). Beni comuni e cooperazione. Bologna, IT: il Mulino.

Simon, H.A. (1951). A Formal Theory of the Employment Relationship, Econometrica, 19(3): 293-305. DOI: https:// doi.org/10.2307/1906815

Simpson, B. \& Willer, R. (2008). Altruism and Indirect Reciprocity: The Interaction of Person and Situation in Prosocial Behavior, Social Psychology Quarterly, 71(1): 37-52. DOI: https://doi.org/10.1177/019027250807100106

Tortia, E.C. (2008). Worker well-being and perceived fairness: survey-based findings from Italy, Journal of Socio-Economics, 37(5): 2080-2094. DOI: https://doi.org/10.1016/j.socec.2007.10.005

Tortia, E.C. (2018). The Firm as a Common. Non-Divided Ownership, Patrimonial Stability and Longevity of CoOperative Enterprises, Sustainability, 10, 1023. DOI: https://doi.org/10.3390/su10041023

Tortia, E.C. \& Valentinov, V. (2018). Internal organization and governance. In: B.A. Seaman \& D. Young (Eds.). Handbook of Research on Nonprofit Economics and Management. Second Edition. Cheltenham, UK: Edward Elgar Publishing, pp. 285-299. DOI: https://doi.org/10.4337/9781785363528.00022

Valentinov, V. (2009). Managerial nonpecuniary preferences in the market failure theories of nonprofit organisation, International Journal of Social Economics, 36: 81-92. DOI: https://doi.org/10.1108/03068290910921208 
Van den Bosch, B. (2010). Transition Experiments: Exploring societal changes towards sustainability (PhD thesis). Rotterdam: Rotterdam University. Available at: https://www.researchgate.net/publication/254805538_Transition_ Experiments_Exploring_societal_changes_towards_sustainability [Accessed 27 July 2018].

Weisbrod, B.A. (1977). The Voluntary Nonprofit Sector: An Economic Analysis. Lexington, MA: Lexington Books.

Weisbrod, B.A. (1988). The Nonprofit Economy. Cambridge, MA: Harvard University Press.

Williamson, O.E. (1973). Markets and Hierarchies: Some Elementary Considerations, American Economic Review, 63(2): 316-325.

Williamson, O.E. (1975). Markets and Hierarchies: Analysis and Antitrust Implications: A Study in the Economics of Internal Organization. New York, NY: Free Press.

Young, D.R. (1983). If Not for Profit, for What?. Lexington, MA: Lexington Books.

Young, D.R. (1984). Casebook of Management for Non-profit Organization: Entrepreneurship and Organizational Change in the Human Services. New York, NY: The Haworth Press.

Young, D.R. (2001). Social Enterprise in the United States: Alternate Identities and Forms, paper presented at The EMES Conference on "The Social Enterprise: A Comparative Perspective", 13-15 December 2001, Trento (Italy). 